Meta

Journal des traducteurs

Translators' Journal

\title{
Translating Implication
}

\section{Candace Séguinot}

Volume 30, numéro 3, septembre 1985

URI : https://id.erudit.org/iderudit/004079ar

DOI : https://doi.org/10.7202/004079ar

Aller au sommaire du numéro

Éditeur(s)

Les Presses de l'Université de Montréal

ISSN

0026-0452 (imprimé)

1492-1421 (numérique)

Découvrir la revue

Citer cette note

Séguinot, C. (1985). Translating Implication. Meta, 30(3), 295-298.

https://doi.org/10.7202/004079ar

Ce document est protégé par la loi sur le droit d'auteur. L’utilisation des services d'Érudit (y compris la reproduction) est assujettie à sa politique d'utilisation que vous pouvez consulter en ligne.

https://apropos.erudit.org/fr/usagers/politique-dutilisation/ 


\section{TRANSLATING IMPLICATION}

In studies of the structure of text, the term inference is used to refer to meanings that go beyond information that is specifically stated in a text ${ }^{1}$. I have preferred to speak of 'implication' here as a synonym for inference in this sense because this latter term appears to be restricted to meaning which is understood by reason of the logical structure of a given language (logical presuppositions and causal inferences, for example), and therefore operates on the level of the text itself, and even more frequently to pragmatic inferences, which are a function of the hearer's or reader's frame of reference. Since the translator is not the intended audience, however, the interpretation of inferential meaning in translation focuses rather on the possible inferences in a text, especially where the intentions of the author are perceived. The term implication shifts the focus from the point of view of the receiver of the message to that of the sender and the text itself.

The term implication has another advantage in that an implicit/explicit distinction carries with it the idea of degrees of explicitness. In other words, a message may be more or less obvious depending on the means by which it is expressed and its relationship to other messages in a text. To give one example, a tone of authority carried by punctuation will be less explicit (= more implicit) than the same tone expressed by syntactic or lexical means. The presence of a thematic message will affect the degree to which other messages are perceived.

Implication in the sense in which it has just been described can be analyzed in terms of its source, nature, intent and effect. The following table shows the distinctions which are operative at each of these levels.

source graphological phonostylistic lexical morphological syntactic collocational textual contextual

nature necessary conventional interpersonal idiosyncratic

intent voluntary involuntary

effect appropriate inappropriate

\section{SGURCE OF IMPLICATION}

The graphological level, that is the structure of a text's appearance on a page, carries a message of its own. Though the translator is rarely preoccupied 
by the choice of type face or layout, the constraints of space often influence the choices open to him or her. In this sense, then, a text in the source language carries an inherent message as to potential parameters for length and even number of words. As a translator working for a company dealing in food products once said, "Doesn't matter how good it is, if it won't fit on the box top."

Another kind of secondary message carried at the level of graphology is the potential use of the colon $(:)$ in French to signal authority, perhaps through a psychological transfer from what is perceived as a scientific formula. This use is typical of advertising in France for example,

Contre la constipation : Herbesan instantané. (la Maison de Marie-Claire, March, 1977)

In English advertising the colon retains its more usual function of introducing definitions,

Introducing Pioneer Syscom : A totally new kind of high fidelity component system. (The New York Times Magazine Sept. 27, 1981) and the subliminal message of authority is conveyed by abbreviated syntax, hidden imperatives and the period :

Convalescing? Chances are you need home nursing care. (Ottawa Citizen, Oct. 20, 1981) A quiet reminder about your biggest office problem. Noise. (En Route, June, 1979)

The phonostylistic implications of a text come to the forefront in the translation of literature and in advertising, but enter into the translation of other material as well, as in this excerpt from an administrative letter :

Dès lors que les fonds seront débloqués - et lorsqu'ils le seront - notre programme de compensation pourra être mis en marche.

In this instance the alliteration of "Dès lors" and "lorsqu'ils" has a stylistic rather than an informational value. Since the primary function of this text is informative rather than aesthetic, and the effect is not easily reproduced in English, the alliteration would fall by the wayside in the translation. On the other hand, there are cases where the phonostylistic structure of the target language imposes constraints on the translator. In a recent speech, André Ouellet as Minister of the Department of Consumer and Corporate Affairs, said, in part,

... tout citoyen canadien devrait avoir à sa disposition les moyens de remédier à la situation financière désastreuse dans laquelle il pourrait se trouver.

Although 'remédier à can be translated '(to) remedy', 'the/a means of' would call for the nomi- nalization 'of remedying' which juxtaposes two [iy] sounds, an example of a close, unmotivated repetition that is jarring. The official translation came out "resolving". So that viewing a text which is wellwritten, a translator must be aware that certain words or combinations of words may have been chosen to conform to preferences or aversions on the level of sound or rhythmic structure.

Implication on the lexical and morphological levels involve the indirect conveyance of information, as in this example which appeared in The Globe and Mail :

"I gather that we haven't had any feedback from them." William Foster, deputy minister of Natural Resources, said in a telephone interview.

"Gather" allows the bureaucrat to avoid saying, "I don't know myself first-hand, but somebody told me."

"Do you want me to read my latest poem ?" more strongly implies that I consider myself a poet than "Do you want me to read one of my poems ?"

One syntactic form of implication that French-English translators are well aware of is surfaces with the translation of referents. Referring to a person by their profession - l'avocat a souligné que... - may be a way of avoiding ambiguity of reference caused by the pronominalization of nouns by grammatical gender.

Implications of syntactic structure can guide a translator to intented meanings of lexical items, as in the following case where the 'but not' signals a distinction in terms which are elsewhere used as synonyms

Chrétien said the word ["existing"] was added to the clause at the insistance of Alberta Premier Peter Lougheed, who in return dropped his earlier demand that native rights should be affirmed, but not recognized. (Ottawa Citizen, Nov. 24, 1981)

Collocational implication includes indications of register - "It is not entirely unlikely that this bill will meet with some opposition." - and indications of approbation or disapproval - "He worked a small bank loan into a million dollar business."

A coherent text of any length carries with it the implication that the genre will be consistent and continued. This implication is precisely what allows the translator to compensate for losses of style through adaptation. The following ad for Aubade is set up like a recipe :

Deux bonnets avec juste ce qu'il faut d'écume de dentelle.

Ajoutez à cela deux fines bretelles, un soupçon de ruse, et deux petites notes d'innocence. 


\author{
Et voilà le retour, tout en douceur, \\ de la vraie féminité. \\ Voilà le nouveau soutien-gorge d'Aubade. \\ Appelons-le : \\ INGÉNUE-LIBERTINE 148 \\ (Marie-Claire, March, 1977)
}

Recognition of the stylistic feature of recipes in English allows us to avoid the indelicate 'cups' in English to come up with,

Take just the right amount of frothy lace...

Contextual implication refers to both situational and cultural input into the interpretation of meaning. "I can't believe you" can be a statement of fact, an expression of affection, or a way of remonstrating with someone for their behaviour. Canada has a postal code, not a zip code and a Charter of Rights and Freedoms, not a Bill of Rights, because the latter terms are identified with the United States.

\section{NATURE OF IMPLICATION}

Some implications follow necessarily from a given use of language - the logical presuppositions of the "when did you stop beating your wife ?" variety. Others are understood by convention and depend on a particular frame of knowledge for their interpretation. In France, for example, Rivoire and Carret pasta built an advertising campaign around an appeal to chauvinism :

En Bourgogne on ne se contente pas de manger les nouilles au beurre. (Elle, August, 1973)

In a case like this it is not clear that, as Claude Tatilon has suggested, "au plan de l'expression ... son [celle de la publicité] écriture ... est toujours un texte facile à comprendre..." 2 The reader has to be familiar with the fact that competing brands of pasta in France have Italian names and that in family-type restaurants in Italy, pasta is often served without sauces, in order to understand the true message of the text. In fact, advertising can generally be reduced to an appeal to very basic motivations which are often expressed through extended metaphors. This means that the implications in ads are very like the private codes that mark interpersonal communication, with the difference that their meanings are understood at least on a subliminal level by a large portion of the target population.

Sociolinguistic divisions in a population also lead to conventional uses of language to mark ingroups and out-groups. Language can therefore have implications for one group that it would not have for outsiders. These implications are carried by variations in register, which reflect power relations within an organization, specialized vocabulary (aircraft versus airplane or plane), and indirect references to shared knowledge. A translator, as an outsider, faced with the following statement from a recent government press release on policy concerning satellite receiving dishes,

... the matter will be given careful consideration in the context of an overall broadcasting strategy currently being developed by the federal government. (The Ottawa Citizen, Jan. 26, 1982)

will understand that the people concerned do not wish to come to a decision at this time on the request to legalize 'pirate' dishes, but will he or she be able to interpret what Frank Howard, the Citizen's commentator on the Ottawa bureaucracy, says is the coded meaning of this phrase, namely, "we are going to look after the interests of existing licence-holders first" ?

Interpersonal communication involves what William Labov and David Fanshell have called implicit propositions which "build the fabric of conversational interaction"3. Again, the problem is that the translator can only be privy to surface meaning in such communication. The cases where translators are faced with idiosyncratic uses of languages are much more frequent and can be used to illustrate the problem of interpreting these kinds of implications. René Lévesque, speaking of his disgust at the outcome of the federal - provincial talks on patriation of the Canadian Constitution, accused the provincial premiers of being "marchands de tapis". This was variously translated by the English media as rug merchants, carpet-baggers and travelling salesmen. In a European context the relationship between the connotative and the denotative meanings of the term may have been clear; in Canada, it was not.

\section{INTENT AND EFFECT}

This brings us to the most important aspect of implication for a translator, namely the problem of choosing between different ways of translating a text. The factors which enter into such a decision involve the voluntary or involuntary nature of implication and its appropriateness or inappropriateness.

Errors are the prime example of inappropriate implications - they reflect badly on the author, and are normally cleaned up by the translator. One example taken from a letter is when a writer does not understand the meaning of a word, as in "veut rester au statu quo actuel" or "students who are facile in English" (meaning have some facility in). As language is always changing, the use of elements in a state of change may carry involuntary implications. Compare these two uses of the word 'terse' :

He made a terse statement when he emerged from the courtroom (brief and angry)

Make your statement terse (brief, not wordy) 
Voluntary uses of implication can also be inappropriate, depending on the audience which receives the message. Advertising typically addresses a target market but with the sensitization to feminist issues, advertising specifically aimed at women has been ruled sexist ${ }^{4}$. Language simplification makes written material easier to assimilate, but since it involves the use of more direct and familiar language, it carries with it the implication of familiarity which may irk more reserved Canadians. And finally, for translators, there remains the problem of voluntary implication which is appropriate. When a writer means to imply rather than directly state something, as in this ad,

Arithmétiquement, Contrex vous aide à ne pas grossir. (la Maison de Marie-Claire, June, 1976)

it is sometimes to mislead the unwary reader. Student translators faced with this sentence fall into the trap of understanding 'statistically'.

How do expert translators treat implication ? There are some indications that in fields where information is paramount, translators not only avoid inappropriate implications, they make more explicit information which could have been retained in an implied form. Here is an example from le Monde and its translation which appeared in the Guardian Weekly :

C'est la caractéristique principale de cette Assemblée, que, multinationale, elle soit organisée, non pas selon les nationalités qui la composent, mais selon les tendances politiques de ses membres.

The main characteristic of the European Assembly is that although multinational it is mostly organised not along national lines, but according to the political tendencies of its members.

Although it is true that appositions play a larger role in the French journalistic rhetorical tradition than in the English, it still seems an interesting hypothesis that translators, like interpreters, process meaning globally ${ }^{5}$. If this is the case, one would expect that the maintaining of degrees of implication would be an interesting problem area for translators.

\section{CANDACE SÉGUINOT}

Notes

1. For example, M.A.K. Halliday and R. Hasan (1976) : Cohesion in English, London, Longman, p. 328.

2. Claude Tatilon (1979) : "Pour une sémantique textuelle : Analyse du texte publicitaire", Sixième colloque de la Société internationale de linguistique fonctionnelle, p. 3 .
3. W. Labov and D. Fanshell (1977) : Therapeutic Discourse, New York, Academic Press, p. 51

4. M. Carrier (1979) : "La femme imaginaire de la publicité", Protégez-vous, septembre, pp. 4-7.

5. D. Seleskovitch (1976) : Langage, langues et mémoire, Paris, Minard. 